\title{
Understanding Fake News Consumption: A Review
}

\author{
João Pedro Baptista ${ }^{1,2}$ (1) and Anabela Gradim ${ }^{1,2, *}$ \\ 1 Department of Communication, Philosophy and Politics, University of Beira Interior (UBI), \\ 6201-001 Covilhã, Portugal; joao.pedro.baptista@ubi.pt \\ 2 Labcom.IFP-Communication and Arts, University of Beira Interior (UBI), 6201-001 Covilhã, Portugal \\ * Correspondence: agradim@ubi.pt
}

Received: 16 September 2020; Accepted: 6 October 2020; Published: 16 October 2020

\begin{abstract}
Combating the spread of fake news remains a difficult problem. For this reason, it is increasingly urgent to understand the phenomenon of fake news. This review aims to see why fake news is widely shared on social media and why some people believe it. The presentation of its structure (from the images chosen, the format of the titles and the language used in the text) can explain the reasons for going viral and what factors are associated with the belief in fake news. We show that fake news explores all possible aspects to attract the reader's attention, from the formation of the title to the language used throughout the body of the text. The proliferation and success of fake news are associated with its characteristics (more surreal, exaggerated, impressive, emotional, persuasive, clickbait, shocking images), which seem to be strategically thought out and exploited by the creators of fake news. This review shows that fake news continues to be widely shared and consumed because that is the main objective of its creators. Although some studies do not support these correlations, it appears that conservatives, right-wing people, the elderly and less educated people are more likely to believe and spread fake news.
\end{abstract}

Keywords: fake news; media consumption; social media; political ideology

\section{Introduction}

The way we access news articles and how we generally consume information online has changed. Social media has become the main vehicle for accessing news. Recent studies show that Facebook is one of the preferred sources of access to news, especially for the younger generation (Newman et al. 2019). However, Facebook and Twitter are responsible for the proliferation of fake news in the digital universe, increasing its exposure through the creation of segregated groups or recommendation algorithms (Zimmer et al. 2019a, 2019b). Our review intends to show why fake news is persuasive and which factors contribute to its spreadability. In addition to being important to understand the digital mechanisms that promote the proliferation of fake news, it is crucial to understand the role the structure (subject, title, body text) plays in its rapid dissemination and what motivates readers to consume and share it. In recent years, several studies have sought to develop effective solutions to combat online disinformation. If on the one hand, efforts are joined in the search for technological programs that allow the identification and detection of fake news (Burkhardt 2017b; Hardalov et al. 2016), on the other hand, others seek to raise the awareness of social media users and decrease the circulation of lies through a bet on the automation of fact-checking (Graves 2018; McClure 2017; Nguyen et al. 2019). The identification of malicious social bots (Davis et al. 2016; Shao et al. 2017; Ferrara 2017; Bessi and Ferrara 2016; Zimmer et al. 2019a) the detention of false content, through linguistic analyses that take into account the text structure (Hardalov et al. 2016; Shu et al. 2018a; Horne and Adali 2017), the frequency of words and the patterns used, are part of a set of solutions that seems to indicate a promising way forward. The development of recommendation algorithms, which promote the 
diversity of content and combat confirmation bias, has been one of the major objectives of recent research (Mohseni and Ragan 2018; Lex et al. 2018; Hou et al. 2018). However, few studies have focused on the structural characteristics of fake news. This review seeks to be an addition to the literature, and its main objective is to analyze the phenomenon of fake news from the perspective of the consumer and to understand the characteristics of fake news articles that motivate their viral spread and which factors are associated with the selection and consumption of fake news in an online environment, in the search to define a profile for the true consumer of online disinformation.

This review focuses on consumer motivations (user/reader) and the structure/presentation of fake news to ascertain the apparent success and proliferation of this type of online disinformation. The factors associated with the dynamics of social media (recommendation algorithms, echo chambers, filter bubbles, malicious social bots) that also contribute a lot to the spread of fake news, were not addressed. With this review, we intend to understand the phenomenon of isolated fake news, in an independent approach to the characteristics of the digital universe to which it belongs. Our goals are to identify the main factors that influence fake news' belief and sharing and to identify differences and similarities between fake news and real news, in order to highlight the relevance of these characteristics for their dissemination. We know that some stories are more likely to go viral than others; that some headlines are more attractive, and that users tend to select information based on their party and ideological identity and on their social and psychological characteristics. Moreover, recent literature has shown that the concept of "fake news" has taken on different meanings, which has led several academics to try to formulate, without success, a univocal definition. The concept became increasingly more subjective and started to be applied in different scenarios and contexts, expanding its semantic field. In this review, we also seek to establish a working definition of fake news, pertinent and relevant to the contemporary debate in the field of journalism and political communication.

Based on a comprehensive literature review, our study aims to answer the following research questions:

- Q1: Does fake news spread quickly on social media because it explores aspects that are attractive to the user/reader?

- $\quad$ Q2: What are the main motivations for sharing fake news on social media?

- Q3: How do demographic and political aspects relate to the belief and dissemination of fake news?

- Q4: Who are fake news consumers?

Regarding research design, the article was organized in different sections, from a brief historical approach to fake news, to the discussion of the various aspects related to the consumption, spread and belief in fake news. In a nutshell, firstly, we identified some epistemological problems, existing in the literature, in relation to "fake news" terminology. We offer a working definition of fake news, focused on its current relevance for contemporary debate in the field of journalism and political communication, clarifying its semantic field. Subsequently, we establish a relationship between the structure of fake news and the user/reader preferences, in order to understand what motivates its consumption and dissemination on social networks. Finally, the article seeks to answer an imperative question: "Who are the consumers of fake news?", completing a thorough review of recent literature (2016-2020) to establish the main factors that influence belief in fake news.

\section{Methods}

The research documents analyzed in this work were extracted from the Google Scholar database. This review considered the studies published between the period 2016 and 2020. The research documents selected were those which, over these years, had the highest number of citations. Scientific articles were evaluated according to the document type, language and inclusion in the thematic category of our review article. Our corpus of the scientific articles considered for the investigation was obtained selecting the articles that evaluate the main factors influencing the belief in fake news. Based on this category (texts dealing with belief in fake news), from the collection of 419 results 
surveyed, we selected 52 scientific articles based on the most consistent, recurring and studied factors by the academic community in relation to the consumption of fake news. Research queries (fake news share), (fake news consumption), (belief fake news) were used in June 2020 to collect the 419 academic documents with the term "fake news" in title, abstract and/or keywords.

\section{Brief Historical Approach to Fake News}

We all know that the fake news phenomenon is not new. However, the tools or methods employed currently are different (Posetti and Matthews 2018; Uberti 2016). Deformation of facts, biased information, advertising and information used to discredit beliefs and values have always been part of society. What could be similar, in ancient times, to what is currently called fake news, may have served as a political maneuver even in Roman times, in 44 BC (Posetti and Matthews 2018). There is various evidence over the centuries that fake news may have always existed.

For example, in Rome, there was a person well known since the 16th century as Pasquino, that was used to disseminate false information and unpleasant rumors to discredit and defame public figures and politicians (Burkhardt 2017a; Canavilhas and Ferrari 2018; Darnton 2017). Additionally, in France, around the 17th century, there was a kind of newspaper, "Canard", which sold fake news on the streets of the French capital (Darnton 2017). Fake news was also spread in Germany in the 19th century. Mcgillen (2017) investigated the techniques used by the creators of fake news during this period, and argued that the misinformation could be related to the creation of fake foreign correspondents in the press to deal with an increasingly competitive market (Mcgillen 2017). As sending correspondents abroad was very expensive, there were fake reporters who made up attractive stories. This reason may indicate that, as it happens today, in the 19th century the motivation for the creation of fake news was also economically and financially based (Bernal 2018).

Being nor recent, nor invented by Donald Trump, fake news has attained an unprecedented influence and reach due to the current media ecosystem. Burkhardt (2017a) divides the history of fake news into four eras: Pre-printing press era, post-printing press era, mass media era and internet era (Burkhardt 2017a). The author says that in the first era (the pre-printing press), fake news was about information control, where knowledge is also power. It gives the example of Procopius of Caesarea who used the spread of false information to discredit Emperor Justianian in the sixth century (Burkhardt 2017a). The Canard in France and Pasquino in Italy characterize the post-printing press era. In the mass media era, the radio show "Broadcasting the Barricades" broadcasted fake news as a parody in 1926, alarming the unknowing population, stands as an example (Burkhardt 2017a). Finally, in the internet age category, fake news has been spread and widely shared, with the most known episodes being the "Pizzagate conspiracy" and the Pope's endorsement of Donald Trump candidacy.

\section{Contemporary Usage}

According to Watson (2018b) the term was first coined in the late 19th century by Merriam Webster (Watson 2018b). Prior to this date, the term fake news was used merely to designate false news. Note that "fake news" does not assume the same meaning as "false news". Meneses (2018) argues that both may have similar but never equal meanings. For the author, the difference is in the intention with which the lie is produced and disseminated. False news is associated with journalistic error, lack of competence and irresponsibility, while fake news relates to "false information" that was deliberately intended and intentionally misleading (Meneses 2018). Meneses (2018) states that the term false news has always existed, unlike fake news, which has only been around for the past 20 years. The neologism is the result of technological advancement, the internet and social media.

The term became popular during the 2016 US presidential election. The concept became an instrument or political weapon of Trump's campaign, used recurrently in his speeches. However, it was Hillary Clinton who brought the term fake news to the campaign, in an intervention that accused the false propaganda circulating on social media. Quickly, Donald Trump assumed the term and began using it repeatedly on twitter, making it viral (Wendling 2018). 


\section{Defining Fake News: A Current Problem}

There is still no consensual definition of fake news in the literature. Despite the extensive use of this terminology that has been made by the academy, the media and politicians, the truth is that defining the concept of fake news has not been easy. Although the term fake news may exist since the 19th century (Watson 2018b), its meaning has undergone several changes over the years, becoming popular in 2016, during the American presidential election campaign (Meneses 2018). Since then, the concept of fake news has been repeated in the media context, which has made its meaning more equivocal. Due to the dimension that the concept acquired, "fake news" became the most popular term in 2016, being the most searched on the Google search engine (Zaryan 2017). In 2017, the Collins Dictionary also decided to name the terminology as the word of the year. Donald Trump was the politician, as a candidate for the White House in 2016, who popularized the term. Trump started using the concept repeatedly to label all journalism that did not favor his campaign (Farkas and Schou 2018). So, since the American elections, fake news has been mostly used to promote ideologies or to make money (Lazer et al. 2018).

The polysemy acquired by the word fake news causes several authors to contest the use of the term. Habgood-Coote (2019) argues that the terminology has been used incorrectly by journalists and scholars, stating that the term fake news does not have a stable meaning and is dependent on various contexts (Habgood-Coote 2019). Moreover, Habgood-Coote (2019) considers the terminology "absurd" and unnecessary, due to the multiplicity of definitions and serves for propaganda uses that can jeopardize democracy (Habgood-Coote 2019). Precisely because of the panoply of definitions around fake news, the European Commission's report chose to use only the terminology "disinformation" (Cock Buning 2018). The choice of disinformation, by the European Commission report, covers a broader spectrum of false or fraudulent information, with a deliberate intention to deceive, in various formats (e.g., memes, manipulated texts) in which fake news fits (Ireton and Posetti 2018). However, most of the literature puts the concept of fake news as corresponding to the format of a news story, from which it gains greater interest and credibility. Even so, the concept of fake news can be an oxymoron, because news must report a true and factual situation (Tandoc et al. 2018b). We are currently witnessing a "shift to post-truth, trading, heavily on assumptions about an "era of truth" we apparently once enjoyed" (Corner 2017).

But what is fake news? In this section we will try to create a definition of fake news based on an analysis of the definitions in the literature, taking into account the context and the importance of the term. Most authors consider fake news to be an article that mimics the format of a news story or report, with fake content that was created with the intent to deceive (Allcott and Gentzkow 2017; Lazer et al. 2018; Rini 2017; Shu et al. 2017; Gelfert 2018; Tandoc et al. 2018b). In fact, it is the intention to deceive that makes it possible to distinguish between fake news and false news (Meneses 2018). False news is not intended to mislead the reader. The false content of a report or piece of news may result from a journalistic error or the journalist's lack of professionalism in verifying its sources (Nielsen and Graves 2017; Gelfert 2018; Meneses 2018). The very word "fake" refers us to the intention to deceive and to lie. "Fake" is associated with counterfeiting, imitating the real (Fallis and Mathiesen 2019; Gelfert 2018). Fake news seeks to be credible and gain legitimacy by imitating the format of the reports or news, in order to manipulate and deceive the reader and make the fake content look real (Blokhin and Ilchenko 2015; Levy 2017; Lazer et al. 2018). It is important to highlight that we approach contemporary fake news, that is, in an online context, in which false statements are widely shared in the digital universe, namely in social media. The goal of contemporary fake news is to go viral (Rini 2017; Meneses 2018; Calvert et al. 2018). For these reasons, fake news can take the form of a news feed post (in the case of Facebook) or a tweet (in the case of Twitter), just like the real news is presented on these social media (headline, image, signature/source). In addition, fake news links to sites that mimic real news sites (Silverman 2016). 
Fallis and Mathiesen (2019) consider fake news to be counterfeit news, which falsifies what is genuine and true (Fallis and Mathiesen 2019). As in art, for example, valuable paintings or coins are falsified, fake news falsifies news.

On the other hand, most authors believe that fake news does not have to be $100 \%$ false or manufactured. Fake news is totally or partially false (Tandoc et al. 2018b; Gelfert 2018; Rini 2017; Allcott and Gentzkow 2017; Potthast et al. 2017; Kalsnes 2018; Recuero and Gruzd 2019), follows the media agenda and trys to describe real events, distorting and manipulating the truth (Rini 2017; Canavilhas et al. 2019).

Even so, the concept of fake news has been widely contested in relation to the "deliberate intention to deceive". Some authors do not consider the intention of the creator of fake news to be fundamental (Pepp et al. 2019; Walters 2018; Jaster and Lanius 2018). The authors wonder about the intention to deceive young Macedonians who, from a small town, created and disseminated fake news during the American elections. Jaster and Lanius (2018) argues that young people simply did not care about the truth (Jaster and Lanius 2018). The intention may have been only financial (through advertising revenue from online clicks). Young people publish any story for financial gain (Fallis and Mathiesen 2019). The same question is necessary to assess the intention of bots, in the possibility of creating fake news. However, the question of bot intent should not be assessed in this way, but rather the intention of the human mind behind bots or artificial intelligence. Moreover, Pepp et al. (2019) argue that fake news simply does not match editorial criteria and journalistic practices, regardless of the producer's intention (Pepp et al. 2019). Fake news is related to the wide dissemination of content that seems to have been treated with journalistic rigor, but that does not obey such practices.

In view of this problem imposed by the difficulty in defining fake news, we believe that it is important to establish a "working definition" of terminology that allows us to respond to the new challenges of journalism and communication. Many studies (Mulroy 2019; Rubin et al. 2015; Verstraete et al. 2017; Watson 2018a; Wardle 2017; Weiss et al. 2020) have sought to categorize fake news, rather than finding a useful definition for contemporary debate. We argue that the creation of a definition of work, eliminating close meanings such as propaganda, publicity, rumors, conspiracy theories or satirical news, is important to avoid emptying the meaning or definition of fake news.

We consider fake news to be "a type of online disinformation, with totally or partially false content, created intentionally to deceive and/or manipulate a specific audience, through a format that imitates a news or report (acquiring credibility), through false information that may or may not be associated with real events, with an opportunistic structure (title, image, content) to attract the readers' attention and to persuade them to believe in falsehood, in order to obtain more clicks and shares, therefore, higher advertising revenue and/or ideological gain."

\section{Consumption and Share of (Fake) News on Social Media}

Sharing news on social media has become customary not only for users/readers, but also for different journalistic organizations looking to generate traffic to their websites by sharing content on social media like Facebook or Twitter (Valenzuela et al. 2017). Whatsapp is also being used to massively disseminate false information. For example, in India, fake news about the conflict between Hindus and Muslims is circulating in different formats (photos, videos) (Khurana and Kumar 2018). Additionally, in Brazil, Whatsapp was, during the 2018 elections, the most used tool to spread fake news. In Brazil, Whatsapp is no longer just a messaging app, it has become a full blown social media network that can influence political ideologies (Gragnani 2018). This mechanism not only changed the form of consumption, but also the production of news content and the profession of journalists. However, social media can symbolize "a double-edged sword" for its users, presenting reliable news articles, but also fake news and disinformation articles in general. The literature shows that the search for social approval (Lee and Ma 2012; Bright 2016), content with emotional impact (Duffy et al. 2019; Harber and Cohen 2005), party and ideological beliefs (Marwick 2018; Uscinski et al. 2016) or the desire to inform "friends" (Galeotti 2019; Duffy et al. 2019) are some of the user's main motivations for sharing news. 
However, users who share fake news also explore some of these motivations. This is why grasping the mechanisms behind news sharing and consumption becomes so important to understand the reasons why fake news continues to be so widely shared and consumed on social media.

Although we cannot consider fake news to be "news", since its information is totally or partially false (Gelfert 2018; Rini 2017) and is created with the aim of deceive or manipulate and misinform (Gelfert 2018; Meinert et al. 2018; Pate and Ibrahim 2020; Tandoc 2019), we recognize that fake news takes on the value of "news", in the sense of bringing "information" or "novelty", even if it is false. Fake news seeks to become legitimate and credible mostly by imitating the format of real news (Lazer et al. 2018; Levy 2017), with similar sources (Tandoc et al. 2018a; Silverman 2016), so if one can consider that the majority of people who share a fake news consider it to be true, it follows that their motivations are similar as when sharing real news.

However, it is known that there may also be people who share fake news with the same intention as those who created it, that is, with the deliberate intention of deceiving, which can be done for different reasons. These spreaders, like the fake news creators, can be motivated by the ambition to attract attention, to denigrate the image of a political candidate, to impose a certain ideological belief or to encourage some type of behavior on users (Lewis and Marwick 2017; Marwick 2018). People who consciously share fake news can do it simply for fun or to create chaos (Vorderer et al. 2004; Coleman 2014). On social media, for both fake news and news, likes, reactions, comments and shares can serve as credibility criteria for other users (Delmazo and Valente 2018), as they may also have implications for how topics are selected, produced and disseminated either by journalists or by fake news producers (Salgado and Bobba 2019).

\section{The Main Motivations for Sharing Fake News}

News sharing can be defined as a common practice of a user who intends, through social media, to make known or recommend content to other people (Kümpel et al. 2015). However, what motivates people to share news? And in what ways are these motivations similar to those of sharing fake news? First, human beings are interested in controversial, surprising or bizarre subjects, which literature has shown to be the ones that motivate greater sharing by users (Duffy et al. 2019; García-Perdomo et al. 2018; Harber and Cohen 2005; Kim 2015). These aspects are common in fake news content, at the same time as covering the same media agenda as the media, they distort information, propagate falsehoods with the formulation of exaggerated stories (Polletta and Callahan 2019), and feed conspiracy theories based on society's fear and panic.

Fake news is mostly made up of sensational and controversial headlines, and their emotional language can contribute to being widely disseminated (Vosoughi et al. 2018). Emotion can be associated with the belief in fake news and the influence and persuasion it have on the public (Martel et al. 2019). Content that encourages strong feelings (positive and negative) such as happiness, excitement or anger is more likely to be shared (Harber and Cohen 2005; Valenzuela et al. 2017; Berger and Milkman 2012). Additionally, García-Perdomo et al. (2018) concluded that the surprise and the drama draw in the user's attention (García-Perdomo et al. 2018).

Second, social relationships and the user's social status or reputation are relevant indicators for news sharing (Lee and Ma 2012; Bright 2016; Duffy et al. 2019). The user feels that his/her social reputation is reinforced, showing his interaction center (friends, private and public groups) that he is "informed" and that he has new and relevant "information". The transmission of a novelty can lead the user to be more easily accepted, especially if it is impressive information, which is mostly consistent with the main characteristics of fake news (Galeotti 2019). The same motivation also promotes involvement in gossip (Talwar et al. 2019). However, Duffy et al. (2019) showed that sharing fake news can have negative effects on interpersonal relationships. Sharing false information can jeopardize the user's entire social reputation. In addition, social media can serve to expose hate speech or vengeful behavior (Fox and Rooney 2015; Garcia and Sikström 2014; Mathew et al. 2019). Associated with these sociological and psychological aspects, the literature has shown that fear of 
missing out (FoMO) is related to the use of social media and can be a factor that contributes to the user's need to share information (Alt 2015; Talwar et al. 2019). FoMO is related to a feeling of anxiety or a psychological reaction that motivates users to try to reinforce their popularity in a certain group, with the aim of obtaining approval and feeling included. FoMO can make people more vulnerable to gossip consumption (Talwar et al. 2019).

Third, false or conspiratorial information is also more likely to be shared if it confirms the user's beliefs and opinions (Uscinski et al. 2016; Marwick 2018), which also justifies the political and ideological importance in their dissemination and the creation of different segregation groups, such as echo chambers and filter bubbles. Social media can contribute to the proliferation of fake news, either through recommendation algorithms or through the characteristics of the media (Bernal 2018; Zimmer et al. 2019a).

The sharing of fake news is still related to the format of fake news, since it is built with the aim not only to deceive, but also to become widely shared online (Rini 2017; Bakir and McStay 2018). All its characteristics (for example, clickbait, exaggerations, controversies, scandalous and dramatic images) draw users' attention to their reading and sharing, with two objectives: to generate advertising revenue and/or obtain ideological gain (Lazer et al. 2018). In fact, sharing fake news can serve as a fraudulent strategy to make money from programmatic advertising on the web, based on online views and clicks. The intention to make easy money by spreading fake news has been one of the main motivations for the creators of fake news. In 2016, there were several sites located in Macedonia that spread false stories about the American elections, in order to make money through Google AdSense advertising (Silverman and Alexander 2016). According to Silverman and Alexander (2016), these young people were not interested in political issues, but in the economic incentives coming from Facebook, which allowed them to generate traffic to their websites (Silverman and Alexander 2016). One of the creators of fake news said in an interview with Inc magazine that he made more than \$10,000 a month in advertising (Townsend 2016).

\section{Turning Fake News Viral}

There is no "magic formula" for fake news to go viral and widely shared, but rather a set of reasons and aspects related to the network and users that can determine the popularity of content (Valenzuela et al. 2017). The popularity of a (fake) news can be conditioned mainly by the relevance/importance of the publication for the audience (Salgado and Bobba 2019; Galeotti 2019; Trilling et al. 2016). This importance is subjective, since this (dis)information may only interest some readers and not all. Rini (2017) considered this factor when defining fake news, saying that its fake content is produced to deceive a part of its audience, although one of the main objectives of fake news is to be widely disseminated. Within the degree of importance that a piece of (fake) news can represent, its popularity can also be related to the characteristics of the coverage of a given event or to the topic being addressed or explored (Vosoughi et al. 2018; Bright 2016; Budak 2019). If we focus, for example, on the top 50 of the most popular fake news items on Facebook, in the United States in 2016, we find that stories about politics were the most viral (Silverman 2016). Fake stories indicating that "Donald Trump was endorsed for President by Pope Francis" or that "the FBI agent, related to the Hillary Clinton email leak, was found dead" were some of the ones that generated the most engagement. In this Top 50, we can find exaggerated and outrageous headlines, with a special focus on "shocking" or "ridiculous" crimes. For example, "Woman arrested for defecating on boss' desk after winning the lottery" is the second most popular fake story, found by surveying a BuzzFeed News investigation (Silverman 2016). Fake news uses topics related to money laundering, crimes, sexual crimes or fraudulent, imaginary and political inventions. These topics, for example, also exist online as misinformation in other countries, so it does not just happen in the United States (see Figure 1). 

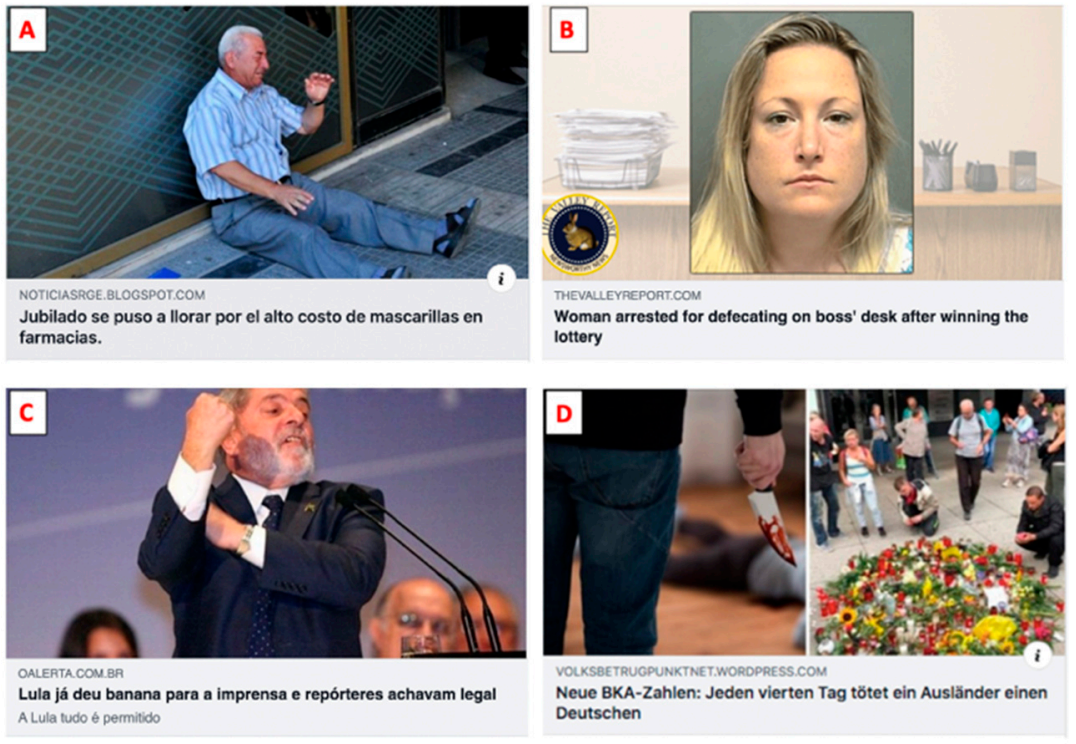

Figure 1. Four fake news items on social media in different countries verified by fact-checkers (Spain, United States, Brazil, Germany). Note: All images (A-D) were taken from fact-checking websites. Image A ('Maldita.es'), image B ('Snopes'), image C ('Lupa') and image D ('Correctiv'). The addresses of sites are described in footnotes. ${ }^{1}$

The choice of headlines was random in order to show examples of false and outrageous titles that exist and are verified by fact-checkers. Figure 1 shows four fake stories in different countries: in Spain (Figure 1A), in the United States (Figure 1B), in Brazil (Figure 1C) and in Germany (Figure 1D). All headlines were checked by the fact-checkers in their countries. In addition to being fake, they all have exaggeration, sensationalism and even violence in common. Figure 1A appeals to the emotional part of the reader, stating that an elderly person is crying for not having money to buy protective masks for the COVID-19 pandemic. The image was manipulated and taken out of context ${ }^{2}$. In Figure 1B, the fake story is unusual, outrageous and impressive ${ }^{3}$. In Figure 1C, the subject criticizes the press for allowing an offensive gesture by former President Lula da Silva, claiming that he bribed the press ${ }^{4}$. In Figure 1D, fake news explores the controversial issue of refugees, blaming them as perpetrators of crimes. The image is shocking and violent ${ }^{5}$.

\subsection{The Role of the Structure of Fake News}

The way in which the structure (for example, from the images chosen, the format of the titles and the language used in the text) of fake news is presented can help explain the reasons for it becoming viral on social media. This analysis intends to focus only on these aspects of fake news, that is, on its formats, content and standards used. We do not address the influence of artificial intelligence, nor the activity of malicious algorithms or bots, nor the spreading techniques in filter bubbles or echo chambers in this section.

Heath (1996) showed that people have a preference for exaggeration, especially if the news is exaggeratedly bad, so (fake) news that presents accidents, disasters or crimes can generate greater emotional sharing (Bright 2016; Heath 1996).

For more information see the following websites.

Figure 1A: https://maldita.es/malditobulo/2020/04/12/abuelo-1lorando-elevado-coste-mascarillas-coronavirus/.

Figure 1B: https://www.snopes.com/fact-check/woman-quits-winning-lottery/.

Figure 1C: https://piaui.folha.uol.com.br/lupa/2020/02/21/verificamos-lula-banana-imprensa/.

Figure 1D: https://correctiv.org/faktencheck/migration/2019/06/14/bei-83-getoeteten-deutschen-2017-waren-auslaendertatverdaechtig-aber-nicht-nur-fluechtlinge. 
Still, fake political news spreads quickly, like that regarding terrorism, natural disasters, urban legends or financial information (Vosoughi et al. 2018). Vosoughi et al. (2018) demonstrate that false content about politics was not only more widely disseminated, but also reached a larger number of people, compared to other subjects. Without specifying the category of false information, these authors showed that falsehood spreads faster than truthful content, stimulating different feelings in those who read it: disgust, fear or surprise (Vosoughi et al. 2018). On the other hand, Humprecht (2019) demonstrated that, unlike the USA and the United Kingdom (where online disinformation is mostly political and partisan), in Germany and Austria, sensationalist stories predominate over political content (E. Humprecht 2019). In an analysis of the fact-checkers in these four countries, the author found that online disinformation in English-speaking countries tends to target political actors, whereas in German-speaking countries, the main focus is immigrants, holding them responsible for current political, economic or social situations. For example, in Brazil and Portugal, one of the main targets of online disinformation is also corruption and politics (Cardoso et al. 2019; ISCTE 2019).

Budak (2019) found that the topics covered during the American elections on Twitter by the traditional media are different compared to fake news agencies. Traditional news focused more on policies related to the economy, elections, women or the environment (Budak 2019). Budak (2019) shows that the coverage of candidates (Hillary and Trump) from the fake news agency is different from the media. The most frequent words used in detected fake news, such as "sex", "death", "corrupt", "illegal", "alien" or "lie", they refer to sensational or outrageous content, unlike traditional media (Budak 2019).

The literature has demonstrated, in fact, that the lexicon used by fake news is more informal and simple in detail and in technical production, not only in the title of the piece, but also throughout the text (Horne and Adali 2017). Several elements taken into account by the producers of fake news, such as simple and impressive messages, with attractive headlines that appeal to the feelings of the public, through clickbaiting, are essential for repeated disclosure (Munger et al. 2018). These factors make the story not only more attractive, but also more persuasive (Wiggins 2017).

In a content analysis, Horne and Adali (2017) found that fake news articles can be distinguished from real news by their lexical coherence. "Real news articles are significantly longer than fake news articles and fake news articles use fewer technical words, smaller words, less punctuation, fewer quotes, and more lexical redundancy" (Horne and Adali 2017). The authors report that fake news needs lower levels of education to be interpreted.

These characteristics allow us to verify that fake news also plays a persuasive role through mostly heuristic methods. In other words, fake news requires less effort and attention (Horne and Adali 2017; Baptista 2020). The association of ideas and the reader's interpretations may be less logical and based only on their titles, since fake titles have significantly more words, have too much content and exaggeration (through hyperbolic words) that resemble clickbait (Horne and Adali 2017; Bazaco et al. 2019). Wiggins (2017) considers that the sensationalist and attractive way in which most fake news is presented fits into the peripheral route of persuasion, which "implies focusing on those elements not central to the argument or message, but paying more attention to how the message is presented" (Wiggins 2017), as opposed to the central route.

\subsection{Is It Too Good or Too Bad? The Importance of Content to Be Viral}

When analyzing what makes fake news viral in the online universe, we also have to take into account the type of news (negative or positive) explored. The literature has shown that fake news uses impressive headlines, reports exaggerated events that provoke a variety of feelings, from joy or enthusiasm (positive), to anger or sadness (negative). This hyperbolic way of presenting fake stories can contribute to it going viral. Salgado and Bobba (2019) concluded that the news on Facebook attracts more attention when the tone is negative (Salgado and Bobba 2019). Heath (1996) also showed that people have a preference for exaggeration, especially if the news is exaggeratedly bad, so (fake) news that presents accidents, disasters or crimes can generate greater emotional sharing (Heath 1996). In fact, 
several studies (Galil and Soffer 2011; Soroka and McAdams 2015) have shown that bad news (such as crises, wars or tragedies) attracts greater public attention (for a summary of the main characteristics that can make fake news viral, see Table 1).

Table 1. Main features of fake news.

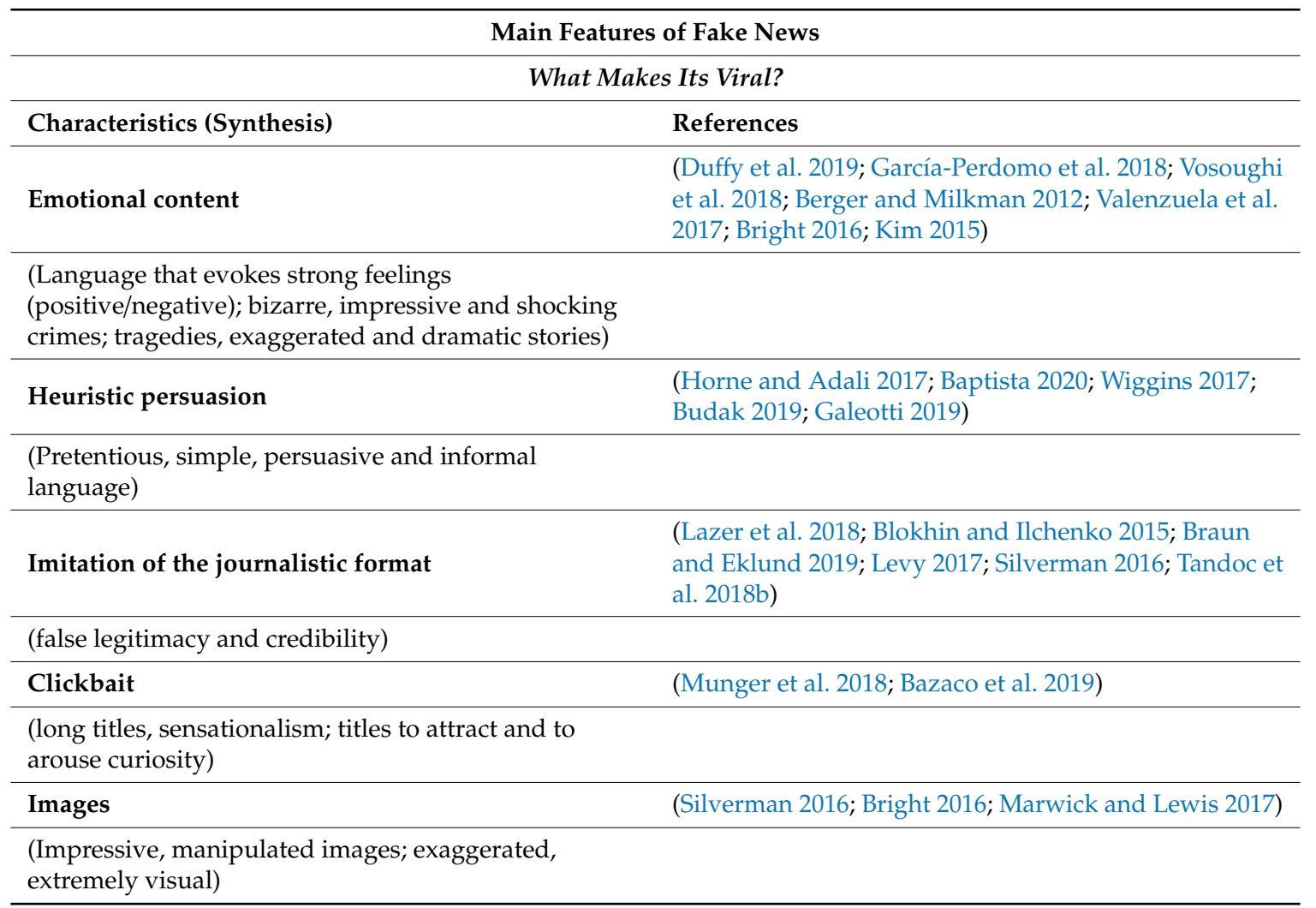

Baumeister et al. (2001) argue that bad events are "stronger" than good ones, noting that bad information is more processed. "The self is more motivated to avoid bad self-definitions than to pursue good ones. Bad impressions and bad stereotypes are quicker to form and more resistant to disconfirmation than good ones" (Baumeister et al. 2001). On the other hand, Berger and Milkman (2012) concluded that virality is related to physiological excitement, which can either be stimulated by strong negative or positive emotions (Berger and Milkman 2012). These stories that evoke strong feelings become more attractive and easily shared.

Weeks and Holbert (2013) showed that virality may be related to whether the content is interesting or emotionally stimulating (Weeks and Holbert 2013). In this sense, Fernandez (2017) stresses that the important thing is to stimulate a reaction, whether by ridiculing or expressing indignation (Fernandez 2017). The author states that the reaction to fake news can be positive (if we think of a cute story) or negative (scandalous disasters), but the crucial thing is that the article leads people to comment and react to the subject. If we look at the fake news that indicated that the Pope had endorsed Donald Trump, Fernandez (2017) argues that in addition to an emotional mix (shock, bewilderment, excitement, indignation), there is still an involvement related to a political and cultural identity, with the mix of religious and political affiliations.

\section{Who Are Fake News Consumers?}

Several investigations have recently sought to understand which factors are associated with the selection and consumption of fake news in an online environment. The belief, consumption and dissemination of fake news may be related to several aspects: for example, the growing distrust in the media (Swift 2016; Nielsen and Graves 2017), the users' level of education (Pop and Ene 
2019; Flynn et al. 2017), age and gender (Shu et al. 2018b; Tanțău et al. 2019; Manalu et al. 2018), party affiliation and ideological identity (Allcott and Gentzkow 2017; Uscinski et al. 2016; Rini 2017), with the availability and time dedicated to social media (Nelson and Taneja 2018) or with our cognitive ability (Pennycook and Rand 2017, 2019b) (see Table 2).

Table 2. Literature review: main factors that influence the belief in disinformation and misinformation online (2016-2020).

\begin{tabular}{|c|c|}
\hline Main Factors & References \\
\hline $\begin{array}{l}\text { Lower Education or } \\
\text { Digital Literacy }\end{array}$ & $\begin{array}{l}\text { (Tandoc et al. 2018a; Craft et al. 2017; Kahne and Bowyer 2017; Leeder 2019; } \\
\text { Douglas et al. 2016; Flynn et al. 2017; Pop and Ene 2019; Reuter et al. 2019) }\end{array}$ \\
\hline $\begin{array}{l}\text { Testimony/proximity of } \\
\text { the relationship }\end{array}$ & $\begin{array}{l}\text { (Sterrett et al. 2019; Turcotte et al. 2015; Burbach et al. 2019; Sterret et al. 2018; } \\
\text { Halpern et al. 2017; Torres et al. 2018; Rini 2017; McNeill 2018; Correia et al. 2019) }\end{array}$ \\
\hline $\begin{array}{l}\text { Partisanship or political } \\
\text { ideological belief }\end{array}$ & $\begin{array}{l}\text { (Swire et al. 2017; Uscinski et al. 2016; Allcott and Gentzkow 2017; Rojecki and } \\
\text { Meraz 2016; Linden et al. 2020; Pennycook and Rand 2019a; Gunther et al. 2018; } \\
\text { Guess et al. 2020; Shin and Thorson 2017; Brandtzaeg and Følstad 2017; Mourão } \\
\text { and Robertson 2019; Marwick 2018; Halpern et al. 2019; Flynn et al. 2017; } \\
\text { Greenhill and Oppenheim 2017; Faragó et al. 2019; Hayes et al. 2018; Jost 2017; } \\
\text { Rini 2017; Barnidge et al. 2020; Galeotti 2019; Mancosu et al. 2017; Pereira and } \\
\text { Van Bavel 2018; Reuter et al. 2019) }\end{array}$ \\
\hline Distrust in the media & $\begin{array}{c}\text { (Bennett and Livingston 2018; Gibson 2018; Marwick and Lewis 2017; Linden et al. } \\
\text { 2020; Brandtzaeg and Følstad 2017; Halpern et al. 2019; Lazer et al. 2018; Tandoc } \\
\text { et al. 2018a; Torres et al. 2018; Nielsen and Graves 2017; Swift 2016; Wasserman } \\
\text { and Madrid-Morales 2019) }\end{array}$ \\
\hline Lower Cognitive ability & $\begin{array}{c}\text { (Pennycook and Rand 2019a; Shin and Thorson 2017; Roets 2017; Celliers and } \\
\text { Hattingh 2020; Leeder 2019; Pennycook and Rand 2017; Čavojová et al. 2019; } \\
\text { Pennycook and Rand 2019b; Bronstein et al. 2019) }\end{array}$ \\
\hline
\end{tabular}

Too much time spent on social media increases the user's exposure to false or illegitimate content, especially if the user has a very active political identity or participation (Halpern et al. 2019). The exposure can also become repeated, making the content more familiar and easily accessible, which can induce a belief (Galeotti 2019). Even though this exposure is later denied by fact-checkers, the user can continue to believe in its content (Pennycook et al. 2018).

Despite this, Halpern et al. (2019) concluded that the use of social media is not related to the belief in fake news. The authors argue that more connected users may have greater knowledge in selecting quality information, exposing themselves less to this type of disinformation (Halpern et al. 2019). It should be noted that some studies have found that the fake news audience is smaller than the real news audience (Allcott and Gentzkow 2017; A. Guess et al. 2019). Regarding the American election period, in 2016, Guess et al. (2019) even mention that some warnings about the echo chambers had been exaggerated, since they estimated that only one in four Americans visited disinformation websites during the elections. In addition, the audience that consumes fake news is not only limited to filter bubbles and echo chambers, since this audience is also exposed, on social media, to real news (Nelson and Taneja 2018).

In Italy and France, in 2017, most fake news sites reached less than $1 \%$ of the online population per month, even though the engagement generated by some fake news on Facebook has exceeded the engagement generated by the most popular real news.

However, this was not the case in most situations (Fletcher et al. 2018). Fake news has a smaller audience than mainstream media, and the levels of distrust in these traditional media sources are lower. Still, online disinformation is currently a political weapon and Facebook is one of the main means of spreading fake news (Bernal 2018), while it remains the preferred social network for accessing news (Newman et al. 2019). What justifies these results? 
The consumption of fake news may be related to the user's availability to use social media. Nelson and Taneja (2018) demonstrated that the selection of information and TV programming has to do with the time available and our schedules, and not exactly with the preferences of the public (Nelson and Taneja 2018). Users with more time available for the internet not only tend to look for other alternative means (Elberse 2008), but are more exposed to all types of information, especially the most popular ones. The time spent on Facebook and Google is positively correlated with the consumption of fake news (Nelson and Taneja 2018). Additionally, the user's level of education can influence the belief in and dissemination of fake news. More educated people, especially young people, are less likely to share false information (Pop and Ene 2019). Flynn et al. (2017) found that the level of education can be a tool in combating the spread of disinformation online (Flynn et al. 2017). Nevertheless, Manalu et al. (2018) found that users aged between 15 and 30 years are more susceptible to believe in fake news, because they are more exposed.

The Digital News Report 2019 points out that young people are not so predisposed to "to work hard for their news", and prefer "easy" and "fun" access (Newman et al. 2019). Some studies (McGrew et al. 2018; Wineburg et al. 2016) have already shown that school and college students have a hard time distinguishing between false and true information. Contrary, in a study that sought to analyze the profiles of users who believed in fake news, it was shown that it is older people and those who are more outgoing and friendly who trust fake news (Shu et al. 2018b).

Munger et al. (2018) concluded that the elderly have a greater preference for clickbait headlines, that is, titles that are designed with the objective of attracting the attention of the reader to click on content of "doubtful value or interest" (Merriam-Webster n.d.; Munger et al. 2018). Consumption can also vary due to gender differences: women are more likely to share false information, although it is men who prefer to consume news through social media (Shu et al. 2018b).

These demographic variables can also be related to the belief and spread of false rumors. Lai et al. (2020) found that women are more likely to believe rumors. The same is true of less literate or educated individuals (Lai et al. 2020). However, the traits related to the personality of each person can also be related to the belief in false rumors, such as people with high values of neuroticism and extroversion (Bordia and DiFonzo 2017; Lai et al. 2020).

From a psychological perspective, several studies (Deppe et al. 2015; Kahan 2013; Pennycook and Rand 2019a, 2019b) found that analytical and intuitive thoughts can interfere with the evaluation of false or true information. According to Pennycook and Rand (2017), the most intuitive individuals are more spontaneous, perform quickly with little attention or intellectual reflection, which turns them more likely to believe in "bullshit" (Pennycook and Rand 2019a), since the majority of the public is limited to reading the headlines (Gabielkov et al. 2016).

Related to this aspect, (Pennycook and Rand 2019a; Swire et al. 2017; Deppe et al. 2015) point out, for example, that liberals tend to be more analytical than conservatives. Conservatives rely more on intuition, so conservatives may be more likely to consume fake news or to believe in "bullshit". Jost et al. (2003) analyzed the social behavior associated with conservatism and found that ideologically right-wing people, in the social sense, have a greater tendency to reject complex topics and are more dependent on implicit reasoning (Jost et al. 2003).

Tetlock (1983) had previously found that conservatism is associated with a more closed mind, which offers resistance to complexity and change, drawing lessons from the world around it through quick judgments, sometimes based on stereotypes (Tetlock 1983).

The belief in fake news can be greater in people prone to delusion, with psychotic thoughts or who follow unusual opinions or ideas such as being aware of conspiracy theories or paranormal phenomena (Douglas et al. 2019).

\section{Political Ideology, Partisanship and the Consumption of Fake News}

The relationship between the producer and the consumer of fake news, as we have seen, is established in a direct and normal way, obeying mechanisms that concern the cognitive field of 
human nature itself. Rini (2017) argues that people govern their belief in certain information based on testimonies. Fake news reaches a user through the testimony of another person, who shared it and accepted it as being true. The testimony is transmitted, especially on social media, often in a biased way, since it comes from someone who has just shared an ideology or expressed a party attachment. This information will be accepted and shared by a recipient who also agrees with these social values (Rini 2017).

Barnidge et al. (2020) demonstrated that selective exposure is driven by political reasons and that users seek to confirm a pre-existing beliefs (Barnidge et al. 2020). Galeotti (2019) argues that belief in fake news is related to motivational factors generally related to people's parties or ideological attachments. People are more likely to accept or reject certain arguments, news or information depending on their political beliefs (Galeotti 2019).

Uscinski et al. (2016) found that partisanship affects belief in a conspiracy theory and that party affiliation tends to assume different attitudes towards different conspiracy theories. Mostly, the tendency is for people to believe that it is the political opposition that is related to conspiracy theories, rumors or illegal activities (Uscinski et al. 2016). However, Uscinski et al. (2016) suggest that both Democrats and Republicans are equally predisposed to accept conspiracy theories. Still, the literature seems to indicate that ideologically right-wing people are more widely connected to conspiracy theories or are more likely to believe, consume and spread fake news (Douglas 2018; Halpern et al. 2019; Lewis and Marwick 2017; Mancosu et al. 2017; Marwick 2018). This belief is mainly associated with people who identify with a right-wing populist political narrative (Mancosu et al. 2017). In fact, the rise of fake news is related to distrust in public and political organizations, namely the media and political elites. McNair (2017) argues that the distrust of the audience and the electorate in general, contributed to the growth of populist and nationalist politicians like Trump or Marine Le Pen (McNair 2017).

The literature has been able to find a positive correlation between populism and conspiracy, with anti-elitist, anti-corruption narratives and a basis on stereotypes and prejudices (A. Marwick and Lewis 2017; Van Prooijen et al. 2015). However, the belief in this type of information does not have to be linked solely to the right, but rather to extremist ideologies of both the right and the left (Van Prooijen et al. 2015). History shows us that the extremist regimes that existed were marked by following some ideas fueled by conspiracy theories, such as communism (on the far left) and fascism (on the far right) (van Prooijen et al. 2018). However, if we look at the most popular fake stories in the US, we can see that the narrative has characteristics that are generally more accepted by the right than by the left.

Douglas (2018) argues that fake news devoted to the right has a religious dimension. The author gives as an example the conspiracy that Clinton was associated with satanic rituals, the fake news that the Pope endorsed Trump, or a series of disinformation linked to the Islamic State or Muslims. On the other hand, this does not mean that people on the left do not consume or spread fake news (Douglas 2018). Douglas (2018) mentioned that fake news directed to the left has Donald Trump as the subject. Allcott and Gentzkow (2017) were even able to verify that Democrats and Republicans have a 15\% probability of believing in ideologically compatible information, even though this percentage is higher in segregated groups (Allcott and Gentzkow 2017). On the other hand, Republicans showed that they were more likely to share fake news that was not of a political nature (Pereira and Van Bavel 2018).

Republicans may be more vulnerable to consuming fake news than Democrats, who have shown themselves to be more "skilled" at distinguishing fake from real articles (Allcott and Gentzkow 2017). Conservatives also may be more exposed to fake news content on social media (Bakshy et al. 2015). However, some authors (Nelson and Taneja 2018; Gentzkow and Shapiro 2011) state that social media users tend to follow the most popular sources, with greater engagement, regardless of their ideology.

\section{Conclusions}

The latest studies on fake news seem to indicate that fake news and disinformation websites reach a small sample of the population, compared to the reach of real news and the traffic generated by 
credible news websites. However, this is no reason to devalue the impact or negative effects of fake news, as it continues to circulate on social media. With this review article, we verified that fake news appropriates all possible aspects to attract the reader's attention, from the way the title of a piece is presented, to the language that is used throughout the article. This language seeks, above all, to be simple, emotional and persuasive.

Regardless of the importance that technology in general-and social media in particular-and the online environment have on the dissemination of online disinformation, fake news is created with the aim of exploring all the "opportunities" and advantages that social media provides them. Fake news only reaches its goals, ideological or financial, if it is widely shared. The creators of fake news seek to explore all possible aspects that can motivate the consumption and sharing of users. The concern of the creators of fake news in making the publication viral or popular starts right away with the choice of the theme to be addressed, in the language they use throughout the text, in the title they attribute to the publication and in the image they use.

Several studies have shown that the fake news agency's agenda is similar to traditional media. Fake news distorts, manipulates and falsifies facts to make the subject more surreal, bizarre, surprising and controversial, and these aspects motivate the sharing by users. Thus, a false story is much more likely to go viral than a real one.

In addition, we found that what motivates the consumption and sharing of fake news continues to merit further investigation. The empirical results presented regarding the demographic dimensions, and the consumption of fake news, are not unanimous. On the other hand, the belief in fake news is closely related to the motivational factors that imply party, political and ideological affiliations.

Although much of the literature considers right-wing people more likely to believe not only in fake news, since fake news mostly exploits narratives devoted to this ideology, other studies do not support this correlation.

\section{Future Approaches}

The characteristics of the fake news' structure deserve more attention by researchers, in order to understand its wide dissemination in the digital universe. It is increasingly important to monitor the evolution of its online presentation, since fake news adapts according to the digital evolution, acquiring new formats. Future works may address the influence of the new formats not only on fake news, but on disinformation in general, namely internet memes. In addition, it will be important to study the phenomenon of fake news with a wider range of sources, in different scenarios and not so specifically in the US scenario.

Author Contributions: Conceptualization, J.P.B. and A.G.; Methodology, J.P.B. and A.G.; Investigation, J.P.B.; Writing —original draft preparation, J.P.B. and A.G.; Writing—review and editing, J.P.B. and A.G.; Supervision, A.G.; project administration, J.P.B. and A.G. All authors have read and agreed to the published version of the manuscript.

Funding: This research was funded by Portugal's Foundation for Science and Technology (FCT) grant number (SFRH/BD/145497/2019). The APC was funded by LabCom.IFP—Communication and Arts (UIDB/00661/2020).

Conflicts of Interest: The authors declare no conflict of interest.

\section{References}

Allcott, Hunt, and Matthew Gentzkow. 2017. Social Media and Fake News in the 2016 Election. Journal of Economic Perspectives 31: 211-36. [CrossRef]

Alt, Dorit. 2015. College Students' Academic Motivation, Media Engagement and Fear of Missing Out. Computers in Human Behavior 49: 111-19. [CrossRef]

Bakir, Vian, and Andrew McStay. 2018. Fake News and the Economy of Emotions: Problems, Causes, Solutions. Digital Journalism 6: 154-75. [CrossRef]

Bakshy, Eytan, Solomon Messing, and Lada A. Adamic. 2015. Exposure to Ideologically Diverse News and Opinion on Facebook. Science 348: 1130-32. [CrossRef] [PubMed] 
Baptista, João. 2020. Ethos, Pathos e Logos. Análise Comparativa Do Processo Persuasivo Das (Fake) News. Eikon 1: 43-54. Available online: http://ojs.labcom-ifp.ubi.pt/index.php/eikon/article/view/816 (accessed on 3 September 2020).

Barnidge, Matthew, Albert C. Gunther, Jinha Kim, Yangsun Hong, Mallory Perryman, Swee Kiat Tay, and Sandra Knisely. 2020. Politically Motivated Selective Exposure and Perceived Media Bias. Communication Research 47: 82-103. [CrossRef]

Baumeister, Roy F., Ellen Bratslavsky, Catrin Finkenauer, and Kathleen D. Vohs. 2001. Bad Is Stronger than Good. Review of General Psychology 5: 323-70. [CrossRef]

Bazaco, Ángela, Marta Redondo, and Pilar Sánchez-García. 2019. Clickbait as a Strategy of Viral Journalism: Conceptualisation and Methods. Revista Latina de Comunicación Social 74: 94.

Bennett, W. Lance, and Steven Livingston. 2018. The Disinformation Order: Disruptive Communication and the Decline of Democratic Institutions. European Journal of Communication 33: 122-39. [CrossRef]

Berger, Jonah, and Katherine L. Milkman. 2012. What Makes Online Content Viral? Journal of Marketing Research 49: 192-205. [CrossRef]

Bernal, Paul. 2018. Fakebook: Why Facebook Makes the Fake News Problem Inevitable. Northern Ireland Legal Quarterly 69: 513-30.

Bessi, Alessandro, and Emilio Ferrara. 2016. Social Bots Distort the 2016 US Presidential Election Online Discussion. First Monday 21: 11-17.

Blokhin, Igor Nikolaevich, and Sergey Nikolaevich Ilchenko. 2015. Fake as a Format of Modern Journalism: The Information Reliability Problem. Indian Journal of Science and Technology 8: 84840. [CrossRef]

Bordia, Prashant, and Nicholas DiFonzo. 2017. Psychological Motivations in Rumor Spread. In Rumor Mills. Edited by Gary Alan Fine, Véronique Campion-Vicent and Chip Health. Abingdon-on-Thames: Routledge, pp. 87-102.

Brandtzaeg, Petter Bae, and Asbjørn Følstad. 2017. Trust and Distrust in Online Fact-Checking Services. Communications of the ACM 60: 65-71. [CrossRef]

Braun, Joshua A., and Jessica L. Eklund. 2019. Fake News, Real Money: Ad Tech Platforms, Profit-Driven Hoaxes, and the Business of Journalism. Digital Journalism 7: 1-21. [CrossRef]

Bright, Jonathan. 2016. The Social News Gap: How News Reading and News Sharing Diverge. Journal of Communication 66: 343-65. [CrossRef]

Bronstein, Michael V., Gordon Pennycook, Adam Bear, David G. Rand, and Tyrone D. Cannon. 2019. Belief in Fake News Is Associated with Delusionality, Dogmatism, Religious Fundamentalism, and Reduced Analytic Thinking. Journal of Applied Research in Memory and Cognition 8: 108-17. [CrossRef]

Budak, Ceren. 2019. What Happened? The Spread of Fake News Publisher Content during the 2016 US Presidential Election. In The World Wide Web Conference. New York: ACM, pp. 139-50.

Burbach, Laura, Patrick Halbach, Martina Ziefle, and André Calero Valdez. 2019. Who Shares Fake News in Online Social Networks? Paper presented at the 27th ACM Conference on User Modeling, Adaptation and Personalization, Larnaca, Cyprus, June 9-12; pp. 234-42.

Burkhardt, Joanna M. 2017a. History of Fake News. Library Technology Reports 53: 5-9.

Burkhardt, Joanna M. 2017b. Combating Fake News in the Digital Age. Chicago: American Library Association, vol. 53.

Calvert, Clay, Stephanie McNeff, Austin Vining, and Sebastian Zarate. 2018. Fake News and the First Amendment: Reconciling a Disconnect Between Theory and Doctrine. University of Cincinnati Law Review 86: 99.

Canavilhas, João, and Pollyana Ferrari. 2018. Fact-Checking: O Jornalismo Regressa Às Origens. In Jornalismo Em Tempo de Transformação: Desafios de Produção e de Ação. Edited by Dulcilia Schroeder Butoni. Porto Alegre: Editora Sulina, pp. 30-49. Available online: http://hdl.handle.net/10400.6/6892 (accessed on 15 October 2020).

Canavilhas, João, Maíra Bittencourt, and Marco Antônio Augusto de Andrade. 2019. Conteúdos Virais No Facebook: Estudo de Caso Na Pré-Campanha Das Eleições Presidenciais Brasileiras de 2018. Brazilian Journalism Research 15: 598-625.

Cardoso, Gustavo, Inês Narciso, José Moreno, and Nuno Palma. 2019. Report-Online Disinformation during Portugal's 2019 Elections. Lisbon: MEDIALAB \& Democracy Reporting International.

Čavojová, Vladimíra, Eugen-Călin Secară, Marek Jurkovič, and Jakub Šrol. 2019. Reception and Willingness to Share Pseudo-profound Bullshit and Their Relation to Other Epistemically Suspect Beliefs and Cognitive Ability in Slovakia and Romania. Applied Cognitive Psychology 33: 299-311. [CrossRef] 
Celliers, Marlie, and Marie Hattingh. 2020. A Systematic Review on Fake News Themes Reported in Literature. In Conference on e-Business, e-Services and e-Society. Cham: Springer, vol. 12067, ISBN 9783030450014.

Cock Buning, Madeleine de. 2018. A Multi-Dimensional Approach to Disinformation: Report of the Independent High Level Group on Fake News and Online Disinformation. Luxembourg: Publications Office of the European Union.

Coleman, Gabriella. 2014. Hacker, Hoaxer, Whistleblower, Spy: The Many Faces of Anonymous. New York: Verso Books. Corner, John. 2017. Fake News, Post-Truth and Media-Political Change. Media, Culture E Society 39: 1100-6.

Correia, João Carlos, Pedro Jerónimo, and Anabela Gradim. 2019. Fake News: Emotion, Belief and Reason in Selective Sharing in Contexts of Proximity. Brazilian Journalism Research 15: 590-613. [CrossRef]

Craft, Stephanie, Seth Ashley, and Adam Maksl. 2017. News Media Literacy and Conspiracy Theory Endorsement. Communication and the Public 2: 388-401. [CrossRef]

Darnton, Robert. 2017. The True History of Fake News. NYR Daily. Available online: https://www.nybooks.com/ daily/2017/02/13/the-true-history-of-fake-news/ (accessed on 12 June 2020).

Davis, Clayton A., Giovanni Luca Ciampaglia, Luca Maria Aiello, Keychul Chung, Michael D. Conover, Emilio Ferrara, Alessandro Flammini, Geoffrey C. Fox, Xiaoming Gao, and Bruno Gonçalves. 2016. OSoMe: The IUNI Observatory on Social Media. PeerJ Computer Science 2: e87. [CrossRef]

Delmazo, Caroline, and Jonas Valente. 2018. Fake News Nas Redes Sociais Online: Propagação e Reações à Desinformação Em Busca de Cliques. Media \& Jornalismo 18: 155-69. [CrossRef]

Deppe, Kristen D., Frank J. Gonzalez, Jayme L. Neiman, Carly Jacobs, Jackson Pahlke, Kevin B. Smith, and John R. Hibbing. 2015. Reflective Liberals and Intuitive Conservatives: A Look at the Cognitive Reflection Test and Ideology. Judgment \& Decision Making 10: 314-31.

Douglas, Christopher. 2018. Religion and Fake News: Faith-Based Alternative Information Ecosystems in the US and Europe. The Review of Faith \& International Affairs 16: 61-73. [CrossRef]

Douglas, Karen M., Robbie M. Sutton, Mitchell J. Callan, Rael J. Dawtry, and Annelie J. Harvey. 2016. Someone Is Pulling the Strings: Hypersensitive Agency Detection and Belief in Conspiracy Theories. Thinking $\mathcal{E}$ Reasoning 22: 57-77.

Douglas, Karen M., Joseph E. Uscinski, Robbie M. Sutton, Aleksandra Cichocka, Turkay Nefes, Chee Siang Ang, and Farzin Deravi. 2019. Understanding Conspiracy Theories. Political Psychology 40: 3-35. [CrossRef]

Duffy, Andrew, Edson Tandoc, and Rich Ling. 2019. Too Good to Be True, Too Good Not to Share: The Social Utility of Fake News. Information, Communication \& Society, 1-15. [CrossRef]

Elberse, Anita. 2008. Should You Invest in the Long Tail? Harvard Business Review 86: 88.

Fallis, Don, and Kay Mathiesen. 2019. Fake News Is Counterfeit News. Inquiry, 1-20. [CrossRef]

Faragó, Laura, Anna Kende, and Péter Krekó. 2019. We Only Believe in News That We Doctored Ourselves: The Connection between Partisanship and Political Fake News. Social Psychology 51: 77-90. [CrossRef]

Farkas, Johan, and Jannick Schou. 2018. Fake News as a Floating Signifier: Hegemony, Antagonism and the Politics of Falsehood. Javnost-The Public 25: 298-314. [CrossRef]

Fernandez, Peter. 2017. The Technology behind Fake News. Library Hi Tech News 34: 1-5. [CrossRef]

Ferrara, Emilio. 2017. Disinformation and Social Bot in the Run up to the 2017 French Presidential Election. First Monday 22: 33.

Fletcher, Richard, Alessio Cornia, Lucas Graves, and Rasmus Kleis Nielsen. 2018. Measuring the Reach of 'Fake News' and Online Disinformation in Europe. Reuters Institute Factsheet. Available online: http://www. digitalnewsreport.org/publications/2018/measuring-reach-fake-news-online-disinformation-europe/ (accessed on 15 October 2020).

Flynn, D. J., Brendan Nyhan, and Jason Reifler. 2017. The Nature and Origins of Misperceptions: Understanding False and Unsupported Beliefs about Politics. Political Psychology 38: 127-50. [CrossRef]

Fox, Jesse, and Margaret C. Rooney. 2015. The Dark Triad and Trait Self-Objectification as Predictors of Men's Use and Self-Presentation Behaviors on Social Networking Sites. Personality and Individual Differences 76: 161-65. [CrossRef]

Gabielkov, Maksym, Arthi Ramachandran, Augustin Chaintreau, and Arnaud Legout. 2016. Social Clicks: What and Who Gets Read on Twitter? ACM SIGMETRICS Performance Evaluation Review 44: 179-92. [CrossRef]

Galeotti, Anna Elisabetta. 2019. Believing Fake News. In Post-Truth, Philosophy and Law. Edited by Angela Condello and Tiziana Andina. Abingdon-on-Thames: Routledge, p. 58.

Galil, Koresh, and Gil Soffer. 2011. Good News, Bad News and Rating Announcements: An Empirical Investigation. Journal of Banking E Finance 35: 3101-19. 
Garcia, Danilo, and Sverker Sikström. 2014. The Dark Side of Facebook: Semantic Representations of Status Updates Predict the Dark Triad of Personality. Personality and Individual Differences 67: 92-96. [CrossRef]

García-Perdomo, Víctor, Ramón Salaverría, Danielle K Kilgo, and Summer Harlow. 2018. To Share or Not to Share. Journalism Studies 19: 1180-201. [CrossRef]

Gelfert, Axel. 2018. Fake News: A Definition. Informal Logic 38: 84-117. [CrossRef]

Gentzkow, Matthew, and Jesse M. Shapiro. 2011. Ideological Segregation Online and Offline. The Quarterly Journal of Economics 126: 1799-839. [CrossRef]

Gibson, Timothy. 2018. The Post-Truth Double-Helix: Reflexivity and Mistrust in Local Politics. International Journal of Communication 12: 19.

Gragnani, Juliana. 2018. Um Brasil Dividido e Movido a Notícias Falsas: Uma Semana Dentro de 272 Grupos Políticos No Whatsapp. BBC News. Available online: https:/www.bbc.com/portuguese/brasil-45666742 (accessed on 5 September 2020).

Graves, D. 2018. Understanding the Promise and Limits of Automated Fact-Checking. Reuters Institute for the Study of Journalism Factsheets. Reuters Institute for the Study of Journalism. Available online: https://ora.ox.ac.uk/objects/uuid:f321ff43-05f0-4430-b978-f5f517b73b9b (accessed on 15 October 2020).

Greenhill, Kelly M., and Ben Oppenheim. 2017. Rumor Has It: The Adoption of Unverified Information in Conflict Zones. International Studies Quarterly 61: 660-76. [CrossRef]

Guess, Andrew, Jonathan Nagler, and Joshua Tucker. 2019. Less than You Think: Prevalence and Predictors of Fake News Dissemination on Facebook. Science Advances 5: eaau4586. [CrossRef]

Guess, Andrew M., Brendan Nyhan, and Jason Reifler. 2020. Exposure to Untrustworthy Websites in the 2016 US Election. Nature Human Behaviour 4: 472-80. [CrossRef]

Gunther, Richard, Paul A. Beck, and Erik C. Nisbet. 2018. Fake News Did Have a Significant Impact on the Vote in the 2016 Election: Original Full-Length Version with Methodological Appendix. Columbus: Ohio State University, Unpublished Manuscript. Available online: https://cpb-us-w2.wpmucdn.com/u.osu.edu/dist/d/12059/files/ 2015/03/Fake-News-Piece-for-The-Conversation-with-methodological-appendix-11d0ni9.pdf (accessed on 15 October 2020).

Habgood-Coote, Joshua. 2019. Stop Talking about Fake News! Inquiry 62: 1033-65. [CrossRef]

Halpern, Daniel, Sebastián Valenzuela, and James E. Katz. 2017. We Face, I Tweet: How Different Social Media Influence Political Participation through Collective and Internal Efficacy. Journal of Computer-Mediated Communication 22: 320-36. [CrossRef]

Halpern, Daniel, Sebastián Valenzuela, James Katz, and Juan Pablo Miranda. 2019. From Belief in Conspiracy Theories to Trust in Others: Which Factors Influence Exposure, Believing and Sharing Fake News. In International Conference on Human-Computer Interaction. Berlin: Springer, pp. 217-32.

Harber, Kent D., and Dov J. Cohen. 2005. The Emotional Broadcaster Theory of Social Sharing. Journal of Language and Social Psychology 24: 382-400. [CrossRef]

Hardalov, Momchil, Ivan Koychev, and Preslav Nakov. 2016. In Search of Credible News. In International Conference on Artificial Intelligence: Methodology, Systems, and Applications. Edited by Christo Dichev and Gennady Agre. Cham: Springer International Publishing, pp. 172-80.

Hayes, Timothy, Jacob C Lee, and Wendy Wood. 2018. Ideological Group Influence: Central Role of Message Meaning. Social Influence 13: 1-17. [CrossRef]

Heath, Chip. 1996. Do People Prefer to Pass along Good or Bad News? Valence and Relevance of News as Predictors of Transmission Propensity. Organizational Behavior and Human Decision Processes 68: 79-94. [CrossRef]

Horne, Benjamin D., and Sibel Adali. 2017. This Just in: Fake News Packs a Lot in Title, Uses Simpler, Repetitive Content in Text Body, More Similar to Satire than Real News. Paper presented at the Eleventh International AAAI Conference on Web and Social Media, Montreal, QC, Canada, May 15-18.

Hou, Lei, Xue Pan, and Kecheng Liu. 2018. Balancing the Popularity Bias of Object Similarities for Personalised Recommendation. The European Physical Journal B 91: 47. [CrossRef]

Humprecht, Edda. 2019. Where 'Fake News' Flourishes: A Comparison across Four Western Democracies. Information, Communication $\mathcal{E}$ Society 22: 1973-88. [CrossRef]

Ireton, Cherilyn, and Julie Posetti. 2018. Journalism, Fake News \& Disinformation: Handbook for Journalism Education and Training. Paris: UNESCO Publishing. 
ISCTE. 2019. Disinformation Risks in Portugal's Election More Brazil than Europe? Risk Assessment: Online Manipulation Ahead of the Portuguese Parliamentary Elections. Available online: https://medialab.iscte-iul. pt/desinformacao-risco-de-interferencia-nas-eleicoes-e-reduzido-2/ (accessed on 15 October 2020).

Jaster, Romy, and David Lanius. 2018. What Is Fake News? Versus 47: 207-24.

Jost, John T. 2017. Ideological Asymmetries and the Essence of Political Psychology. Political Psychology 38: 167-208. [CrossRef]

Jost, John T., Jack Glaser, Arie W. Kruglanski, and Frank J. Sulloway. 2003. Political Conservatism as Motivated Social Cognition. Psychological Bulletin 129: 339. [CrossRef]

Kahan, Dan M. 2013. Ideology, Motivated Reasoning, and Cognitive Reflection. Judgment and Decision making 8: 407-24.

Kahne, Joseph, and Benjamin Bowyer. 2017. Educating for Democracy in a Partisan Age: Confronting the Challenges of Motivated Reasoning and Misinformation. American Educational Research Journal 54: 3-34. [CrossRef]

Kalsnes, Bente. 2018. Fake News. In Oxford Research Encyclopedia of Communication. Oxford: Oxford Research Encyclopedia.

Khurana, Pooja, and Deepak Kumar. 2018. Sir Model for Fake News Spreading Through Whatsapp. Paper presented at the 3rd International Conference on Internet of Things and Connected Technologies (ICIoTCT), Jaipur, India, March 26-27.

Kim, Hyun Suk. 2015. Attracting Views and Going Viral: How Message Features and News-Sharing Channels Affect Health News Diffusion. Journal of Communication 65: 512-34. [CrossRef]

Kümpel, Anna Sophie, Veronika Karnowski, and Till Keyling. 2015. News Sharing in Social Media: A Review of Current Research on News Sharing Users, Content, and Networks. Social Media+ Society 1: 2056305115610141. [CrossRef]

Lai, Kaisheng, Xiling Xiong, Xiaoya Jiang, Meiqi Sun, and Lingnan He. 2020. Who Falls for Rumor? Influence of Personality Traits on False Rumor Belief. Personality and Individual Differences 152: 109520. [CrossRef]

Lazer, David M. J., Matthew A. Baum, Yochai Benkler, Adam J. Berinsky, Kelly M. Greenhill, Filippo Menczer, Miriam J. Metzger, Brendan Nyhan, Gordon Pennycook, David Rothschild, and et al. 2018. The Science of Fake News. Science 359: 1094-96. [CrossRef] [PubMed]

Lee, Chei Sian, and Long Ma. 2012. News Sharing in Social Media: The Effect of Gratifications and Prior Experience. Computers in Human Behavior 28: 331-39. [CrossRef]

Leeder, Chris. 2019. How College Students Evaluate and Share 'Fake News' Stories. Library E Information Science Research 41: 100967.

Levy, Neil. 2017. The Bad News about Fake News. Social Epistemology Review and Reply Collective 6: 20-36.

Lewis, Rebecca, and A. E. Marwick. 2017. Taking the Red Pill: Ideological Motivations for Spreading Online Disinformation. In Understanding and Addressing the Disinformation Ecosystem. Philadelphia: Annenberg School for Communication, pp. 18-22.

Lex, Elisabeth, Mario Wagner, and Dominik Kowald. 2018. Mitigating Confirmation Bias on Twitter by Recommending Opposing Views. arXiv arXiv:1809.03901.

Linden, Sander van der, Costas Panagopoulos, and Jon Roozenbeek. 2020. You Are Fake News: Political Bias in Perceptions of Fake News. Media, Culture E Society 42: 460-70.

Manalu, Rouli, Tandiyo Pradekso, and Djoko Setyabudi. 2018. Understanding the Tendency of Media Users to Consume Fake News. Jurnal Ilmu Komunikasi 15: 1-16. [CrossRef]

Mancosu, Moreno, Salvatore Vassallo, and Cristiano Vezzoni. 2017. Believing in Conspiracy Theories: Evidence from an Exploratory Analysis of Italian Survey Data. South European Society and Politics 22: 327-44. [CrossRef]

Martel, Cameron, Gordon Pennycook, and David Rand. 2019. Reliance on Emotion Promotes Belief in Fake News. Cognitive Research: Principles and Implications 5: 1-20. [CrossRef]

Marwick, Alice E. 2018. Why Do People Share Fake News? A Sociotechnical Model of Media Effects. Georgetown Law Technology Review 2: 474-512.

Marwick, Alice, and Rebecca Lewis. 2017. Media Manipulation and Disinformation Online. New York: Data \& Society Research Institute.

Mathew, Binny, Ritam Dutt, Pawan Goyal, and Animesh Mukherjee. 2019. Spread of Hate Speech in Online Social Media. Paper presented at the 10th ACM Conference on Web Science, Amsterdam The Netherlands, May 27-30; pp. 173-82. 
McClure, Laure. 2017. How to Tell Fake News from Real News. TED-Ed. Available online: https://blog.ed.ted. com/2017/01/12/how-to-tell-fake-news-from-real-news/ (accessed on 15 October 2020).

Mcgillen, Petra. 2017. How the Techniques of 19th-Century Fake News Tell Us Why We Fall for It Today. NiemanLab. April. Available online: https://www.niemanlab.org/2017/04/how-the-techniques-of-19th-century-fakenews-tell-us-why-we-fall-for-it-today/ (accessed on 15 October 2020).

McGrew, Sarah, Joel Breakstone, Teresa Ortega, Mark Smith, and Sam Wineburg. 2018. Can Students Evaluate Online Sources? Learning from Assessments of Civic Online Reasoning. Theory E Research in Social Education 46: 165-93.

McNair, Brian. 2017. Fake News: Falsehood, Fabrication and Fantasy in Journalism. New York: Routledge. [CrossRef]

McNeill, Lynne S. 2018. ‘My Friend Posted It and That's Good Enough for Me!': Source Perception in Online Information Sharing. Journal of American Folklore 131: 493-99. [CrossRef]

Meinert, Judith, Milad Mirbabaie, Sebastian Dungs, and Ahmet Aker. 2018. Is It Really Fake?-Towards an Understanding of Fake News in Social Media Communication. In International Conference on Social Computing and Social Media. Berlin: Springer, pp. 484-97.

Meneses, João Paulo. 2018. Sobre a Necessidade de Conceptualizar o Fenómeno Das Fake News. Observatorio $\left(O B S^{*}\right)$ 12. [CrossRef]

Merriam-Webster. n.d. “Clickbait.” Merriam-Webster.com Dictionary. Available online: https://www.merriamwebster.com/dictionary/clickbait (accessed on 15 October 2020).

Mohseni, Sina, and Eric Ragan. 2018. Combating Fake News with Interpretable News Feed Algorithms. arXiv arXiv:1811.12349.

Mourão, Rachel R., and Craig T. Robertson. 2019. Fake News as Discursive Integration: An Analysis of Sites That Publish False, Misleading, Hyperpartisan and Sensational Information. Journalism Studies 20: 2077-95. [CrossRef]

Mulroy, Alexander. 2019. The Truth Still Matters: Teaching Information Literacy to Combat Fake News and Alternative Facts. Master's thesis, Education and Human Development, Minneapolis, MN, USA. Available online: https://digitalcommons.brockport.edu/ehd_theses/1227/ (accessed on 15 October 2020).

Munger, Kevin, Mario Luca, Jonathan Nagler, and Joshua Tucker. 2018. The Effect of Clickbait. Available online: https://www.semanticscholar.org/paper/The-Effect-of-Clickbait-*-Munger-Luca/ 9edda403530e9a45dd0b756ea0b938797dce6a82 (accessed on 15 October 2020).

Nelson, Jacob L., and Harsh Taneja. 2018. The Small, Disloyal Fake News Audience: The Role of Audience Availability in Fake News Consumption. New Media and Society 20: 3720-37. [CrossRef]

Newman, Nic, Richard Fletcher, Antonis Kalogeropoulos, and Rasmus Nielsen. 2019. Reuters Institute Digital News Report 2019. Oxford: Reuters Institute for the Study of Journalism, vol. 2019.

Nguyen, Thanh Tam, Matthias Weidlich, Hongzhi Yin, Bolong Zheng, Quoc Viet Hung Nguyen, and Bela Stantic. 2019. User Guidance for Efficient Fact Checking. Proceedings of the VLDB Endowment 12: 850-63. [CrossRef]

Nielsen, Rasmus Kleis, and Lucas Graves. 2017. 'News You Don't Believe': Audience Perspectives on Fake News. Oxford: Reuters Institute for the Study of Journalism, Available online: https://ora.ox.ac.uk/objects/uuid: 6eff4d14-bc72-404d-b78a-4c2573459ab8 (accessed on 15 October 2020).

Pate, Umaru A., and Adamkolo Mohammed Ibrahim. 2020. Fake News, Hate Speech and Nigeria's Struggle for Democratic Consolidation: A Conceptual Review. In Handbook of Research on Politics in the Computer Age. Hershey: IGI Global, pp. 89-112.

Pennycook, Gordon, and David G. Rand. 2017. Who Falls for Fake News? The Roles of Analytic Thinking, Motivated Reasoning, Political Ideology, and Bullshit Receptivity. SSRN Electronic Journal, 1-63. [CrossRef]

Pennycook, Gordon, and David G. Rand. 2019a. Who Falls for Fake News? The Roles of Bullshit Receptivity, Overclaiming, Familiarity, and Analytic Thinking. Journal of Personality. [CrossRef]

Pennycook, Gordon, and David G. Rand. 2019b. Lazy, Not Biased: Susceptibility to Partisan Fake News Is Better Explained by Lack of Reasoning than by Motivated Reasoning. Cognition 188: 39-50. [CrossRef]

Pennycook, Gordon, Tyrone D. Cannon, and David G. Rand. 2018. Prior Exposure Increases Perceived Accuracy of Fake News. Journal of Experimental Psychology: General 147: 1865. [CrossRef] [PubMed]

Pepp, Jessica, Eliot Michaelson, and Rachel Katharine Sterken. 2019. What's New about Fake News. Journal of Ethics and Social Philosophy 16: 67.

Pereira, Andrea, and Jay Van Bavel. 2018. Identity Concerns Drive Belief in Fake News. PsyArXiv Working Paper. Available online: https://psyarxiv.com/7vc5d/ (accessed on 23 July 2020). 
Polletta, Francesca, and Jessica Callahan. 2019. Deep Stories, Nostalgia Narratives, and Fake News: Storytelling in the Trump Era. In Politics of Meaning/Meaning of Politics. Berlin: Springer, pp. 55-73.

Pop, Mihai-Ionut, and Irina Ene. 2019. Influence of the Educational Level on the Spreading of Fake News Regarding the Energy Field in the Online Environment. In Proceedings of the International Conference on Business Excellence. Warsaw: Sciendo, vol. 13, pp. 1108-17.

Posetti, Julie, and Alice Matthews. 2018. A Short Guide to the History of'fake News' and Disinformation. International Center for Journalists 7. Available online: https://www.icfj.org/sites/default/files/2018-07/A\% 20Short\%20Guide\%20to\%20History\%20of\%20Fake\%20News\%20and\%20Disinformation_ICFJ\%20Final. pdf (accessed on 15 October 2020).

Potthast, Martin, Johannes Kiesel, Kevin Reinartz, Janek Bevendorff, and Benno Stein. 2017. A Stylometric Inquiry into Hyperpartisan and Fake News. arXiv arXiv:1702.05638.

Van Prooijen, Jan-Willem, André P. M. Krouwel, and Thomas V. Pollet. 2015. Political Extremism Predicts Belief in Conspiracy Theories. Social Psychological and Personality Science 6: 570-78. [CrossRef]

van Prooijen, Jan-Willem, B. Rutjens, and M. Brandt. 2018. Populism as Political Mentality Underlying Conspiracy Theories. In Belief Systems and the Perception of Reality. Abingdon-on-Thames: Routledge, pp. 79-96.

Recuero, Raquel, and Anatoliy Gruzd. 2019. Cascatas de Fake News Políticas: Um Estudo de Caso No Twitter. Galáxia (São Paulo) 41: 31-47. [CrossRef]

Reuter, Christian, Katrin Hartwig, Jan Kirchner, and Noah Schlegel. 2019. Fake News Perception in Germany: A Representative Study of People's Attitudes and Approaches to Counteract Disinformation. Available online: https://aisel.aisnet.org/wi2019/track09/papers/5/ (accessed on 23 July 2020).

Rini, Regina. 2017. Fake News and Partisan Epistemology. Kennedy Institute of Ethics Journal 27: E-43-E-64. [CrossRef]

Roets, Arne. 2017. 'Fake News': Incorrect, but Hard to Correct. The Role of Cognitive Ability on the Impact of False Information on Social Impressions. Intelligence 65: 107-10.

Rojecki, Andrew, and Sharon Meraz. 2016. Rumors and Factitious Informational Blends: The Role of the Web in Speculative Politics. New Media E Society 18: 25-43.

Rubin, Victoria L., Yimin Chen, and Niall J. Conroy. 2015. Deception Detection for News: Three Types of Fakes. In Proceedings of the 78th ASISET Annual Meeting: Information Science with Impact: Research in and for the Community. Silver Spring: American Society for Information Science.

Salgado, Susana, and Giuliano Bobba. 2019. News on Events and Social Media: A Comparative Analysis of Facebook Users' Reactions. Journalism Studies 20: 2258-76. [CrossRef]

Shao, Chengcheng, Giovanni Luca Ciampaglia, Onur Varol, Alessandro Flammini, and Filippo Menczer. 2017. The Spread of Fake News by Social Bots. arXiv arXiv:1707.07592.

Shin, Jieun, and Kjerstin Thorson. 2017. Partisan Selective Sharing: The Biased Diffusion of Fact-Checking Messages on Social Media. Journal of Communication 67: 233-55. [CrossRef]

Shu, Kai, Amy Sliva, Suhang Wang, Jiliang Tang, and Huan Liu. 2017. Fake News Detection on Social Media: A Data Mining Perspective. ACM SIGKDD Explorations Newsletter 19: 22-36. [CrossRef]

Shu, Kai, Deepak Mahudeswaran, Suhang Wang, Dongwon Lee, and Huan Liu. 2018a. FakeNewsNet: A Data Repository with News Content, Social Context and Spatialtemporal Information for Studying Fake News on Social Media. arXiv arXiv:1809.01286.

Shu, Kai, Suhang Wang, and Huan Liu. 2018b. Understanding User Profiles on Social Media for Fake News Detection. In 2018 IEEE Conference on Multimedia Information Processing and Retrieval (MIPR). New York: IEEE, pp. 430-35.

Silverman, Craig. 2016. Here Are 50 of the Biggest Fake News Hits on Facebook from 2016. Buzzfeed News. Available online: https://www.buzzfeednews.com/article/craigsilverman/top-fake-news-of-2016 (accessed on 3 September 2020).

Silverman, Craig, and Lawrence Alexander. 2016. How Teens in the Balkans Are Duping Trump Supporters with Fake News. Buzzfeed News. November 3. Available online: https://www.buzzfeednews.com/article/ craigsilverman/how-macedonia-became-a-global-hub-for-pro-trump-misinfo (accessed on 15 October 2020).

Soroka, Stuart, and Stephen McAdams. 2015. News, Politics, and Negativity. Political Communication 32: 1-22. [CrossRef] 
Sterret, David, Dan Malato, Jennifer Benz, Liz Kantor, Trevor Tompson, Tom Rosenstiel, Jeff Sonderman, Kevin Loker, and Emily Swanson. 2018. Who Shared It?: How Americans Decide What News to Trust on Social Media. NORC Working Paper Series WP-2018-001. Chicago, IL, USA: University of Chicago.

Sterrett, David, Dan Malato, Jennifer Benz, Liz Kantor, Trevor Tompson, Tom Rosenstiel, Jeff Sonderman, and Kevin Loker. 2019. Who Shared It?: Deciding What News to Trust on Social Media. Digital Journalism 7: 783-801. [CrossRef]

Swift, Art. 2016. Americans' Trust in Mass Media Sinks to New Low. Gallup News 14 . Available online: https://news.gallup.com/poll/195542/americans-trust-mass-media-sinks-new-low.aspx (accessed on 15 October 2020).

Swire, Briony, Adam J. Berinsky, Stephan Lewandowsky, and Ullrich K. H. Ecker. 2017. Processing Political Misinformation: Comprehending the Trump Phenomenon. Royal Society Open Science 4. [CrossRef]

Talwar, Shalini, Amandeep Dhir, Puneet Kaur, Nida Zafar, and Melfi Alrasheedy. 2019. Why Do People Share Fake News? Associations between the Dark Side of Social Media Use and Fake News Sharing Behavior. Journal of Retailing and Consumer Services 51: 72-82. [CrossRef]

Tandoc, Edson C., Jr. 2019. The Facts of Fake News: A Research Review. Sociology Compass 13: e12724. [CrossRef] Tandoc, Edson C., Jr., Richard Ling, Oscar Westlund, Andrew Duffy, Debbie Goh, and Lim Zheng Wei. 2018a. Audiences' Acts of Authentication in the Age of Fake News: A Conceptual Framework. New Media E Society 20: 2745-63.

Tandoc, Edson C., Jr., Zheng Wei Lim, and Richard Ling. 2018b. Defining 'Fake News': A Typology of Scholarly Definitions. Digital Journalism 6: 137-53. [CrossRef]

Tanțău, Adrian, Mihai Pop, and Alexandra Cătălina Chinie. 2019. Quantitative Analysis Regarding the Probability of Spreading Fake News Based on Age. New Trends in Sustainable Business and Consumption, 649. Available online: https://www.researchgate.net/profile/Ann_Katrin_Arp/publication/333902657_Study_ on_European_funding_programmes_for_sustainable_development/links/5dbaf94d299bf1a47b05a8d3/

Study-on-European-funding-programmes-for-sustainable-development.pdf\#page=649 (accessed on 15 October 2020).

Tetlock, Philip E. 1983. Cognitive Style and Political Ideology. Journal of Personality and Social Psychology 45: 118. [CrossRef]

Torres, Russell, Natalie Gerhart, and Arash Negahban. 2018. Epistemology in the Era of Fake News: An Exploration of Information Verification Behaviors among Social Networking Site Users. ACM SIGMIS Database: The DATABASE for Advances in Information Systems 49: 78-97. [CrossRef]

Townsend, Tess. 2016. The Bizarre Truth behind the Biggest Pro-Trump Facebook Hoaxes. Available online: https://www.inc.com/tess-townsend/ending-fed-trump-facebook.html (accessed on 15 October 2020).

Trilling, Damian, Petro Tolochko, and Björn Burscher. 2016. From Newsworthiness to Shareworthiness: How to Predict News Sharing Based on Article Characteristics. Journalism \& Mass Communication Quarterly 94: 38-60. [CrossRef]

Turcotte, Jason, Chance York, Jacob Irving, Rosanne M. Scholl, and Raymond J. Pingree. $2015 . \quad$ News Recommendations from Social Media Opinion Leaders: Effects on Media Trust and Information Seeking. Journal of Computer-Mediated Communication 20: 520-35. [CrossRef]

Uberti, David. 2016. The Real History of Fake News. Columbia Journalism Review 15.

Uscinski, Joseph E., Casey Klofstad, and Matthew D. Atkinson. 2016. What Drives Conspiratorial Beliefs? The Role of Informational Cues and Predispositions. Political Research Quarterly 69: 57-71. [CrossRef]

Valenzuela, Sebastián, Martina Piña, and Josefina Ramírez. 2017. Behavioral Effects of Framing on Social Media Users: How Conflict, Economic, Human Interest, and Morality Frames Drive News Sharing. Journal of Communication 67: 803-26. [CrossRef]

Verstraete, Mark, Derek E. Bambauer, and Jane R. Yakowitz Bambauer. 2017. Identifying and Countering Fake News. Arizona Legal Studies Discussion Paper 34. [CrossRef]

Vorderer, Peter, Christoph Klimmt, and Ute Ritterfeld. 2004. Enjoyment: At the Heart of Media Entertainment. Communication Theory 14: 388-408. [CrossRef]

Vosoughi, Soroush, Deb Roy, and Sinan Aral. 2018. The Spread of True and False News Online. Science 359: 1146-51. [CrossRef] [PubMed]

Walters, Ryan M. 2018. How to Tell a Fake: Fighting Back against Fake News on the Front Lines of Social Media. Texas Review of Law and Politics 23: 111. 
Wardle, Claire. 2017. Fake News. It's Complicated. First Draft News. Available online: https:/firstdraftnews.org/ fake-news-complicated/ (accessed on 23 May 2020).

Wasserman, Herman, and Dani Madrid-Morales. 2019. An Exploratory Study of 'Fake News' and Media Trust in Kenya, Nigeria and South Africa. African Journalism Studies 40: 107-23. [CrossRef]

Watson, Carol A. 2018a. Digital Literacy: Detecting Fake News in a Post-Truth Era. Continuing Legal Education Presentations, no. 8. Available online: https://digitalcommons.law.uga.edu/cle/2018/schedule/8 (accessed on 13 June 2020).

Watson, Carol A. 2018b. Information Literacy in a Fake/False News World: An Overview of the Characteristics of Fake News and Its Historical Development. International Journal of Legal Information 46: 93-96. [CrossRef]

Weeks, Brian E., and R. Lance Holbert. 2013. Predicting Dissemination of News Content in Social Media: A Focus on Reception, Friending, and Partisanship. Journalism \& Mass Communication Quarterly 90: 212-32.

Weiss, Andrew P., Ahmed Alwan, Eric P. Garcia, and Julieta Garcia. 2020. Surveying Fake News: Assessing University Faculty's Fragmented Definition of Fake News and Its Impact on Teaching Critical Thinking. International Journal for Educational Integrity 16: 1. [CrossRef]

Wendling, Mike. 2018. The (Almost) Complete History of 'Fake News. BBC Trending. January. Available online: https://www.bbc.com/news/blogs-trending-42724320 (accessed on 6 September 2020).

Wiggins, Bradley E. 2017. Navigating an Immersive Narratology: Factors to Explain the Reception of Fake News. International Journal of E-Politics (IJEP) 8: 16-29. [CrossRef]

Wineburg, Sam, Sarah McGrew, Joel Breakstone, and Teresa Ortega. 2016. Evaluating Information: The Cornerstone of Civic Online Reasoning. Stanford Digital Repository 8: 2018.

Zaryan, Stella. 2017. Truth and Trust: How Audiences Are Making Sense of Fake News. Lund: Lund University.

Zimmer, Franziska, Katrin Scheibe, Mechtild Stock, and Wolfgang G. Stock. 2019a. Fake News in Social Media: Bad Algorithms or Biased Users? Journal of Information Science Theory and Practice 7: 40-53. [CrossRef]

Zimmer, Franziska, Katrin Scheibe, Mechtild Stock, and Wolfgang G. Stock. 2019b. Echo Chambers and Filter Bubbles of Fake News in Social Media. Man-Made or Produced by Algorithms. Paper presented at the 8th Annual Arts, Humanities, Social Sciences \& Education Conference, Honolulu, HI, USA, January 3-6; pp. 1-22.

Publisher's Note: MDPI stays neutral with regard to jurisdictional claims in published maps and institutional affiliations.

(C) 2020 by the authors. Licensee MDPI, Basel, Switzerland. This article is an open access article distributed under the terms and conditions of the Creative Commons Attribution (CC BY) license (http://creativecommons.org/licenses/by/4.0/). 